УДК 347.9

DOI https://doi.org/10.32849/2663-5313/2020.6.01

Костянтин Білоус,

аспірант кафедри иивільного прочесу

Начіонального юридичного університету імені Ярослава Мудрого

\title{
СПЕЦАЛЬНІ ПІДСТАВИ КАСАЦІЙНОГО ОСКАРЖЕННЯ СУДОВИХ РІШЕНЬ У МАЛОЗНАЧНИХ СПРАВАХ
}

Стаття присвячена дослідженню змісту спеиіальних підстав допуску малозначних справ до перегляду в суді касаиійної інстаниії. Автором з'ясовано, що запровадження процесуальних фільтрів касаиійного оскарження окремих категорій иивільних справ, в тому числі й малозначних, не суперечить стандартам, викладеним у Рекомендаціях Комітету Міністрів Ради Європи, та суттєво не впливає на рівень ефективності функиіонування правового механізму забезпечення реалізації системи гарантій права на справедливий суд, що знайшло своє відображення у практиці Європейського суду з прав людини. За результатами аналізу чинного процесуального законодавства, зокрема норм, що визначають процесуальні особливості касачійного оскарження судових рішень у малозначних справах, було виокремлено «універсальну» та «спечіальну» групи підстав допуску малозначних справ до перегляду судом касаиійної інстаниії, які співвідносяться автором крізь призму таких діалектичних категорій, як загальне й одиничне.

Встановлено, що для відкриття касачійного провадження у малозначній справі не досить наявності лише спеиіальних підстав, оскільки одиничне не може існувати окремо від загального, яке завжди втілюється в одиничному і реалізується через нього. Малозначну справу може бути допущено до касаиійного перегляду лише за умови комплексності, тобто побіжної наявності однієї з універсальних та спеиіальної підстав касаиійного оскарження судових рішень у малозначних справах. Вони мають застосовуватися у сукупності, а ӥх зв'язок є всеохоплюючим. У статті наводиться авторське тлумачення змісту спечіальних підстав допуску малозначних справ до перегляду судом касаиійної інстаниії, зокрема: 1) питання права, яке має фундаментальне значення для формування єдиної правозастосовчої практики; 2) відсутність можливості в особи, яка подала касачійну скаргу, спростувати обставини, встановлені оскарженим судовим рішенням, під час розгляду іншої справи; 3) значний суспільний інтерес справи; 4) виняткове значення справи для ї̈ учасника; 5) помилковість віднесення судом першої інстанції справи до категорії малозначних.

Ключові слова: малозначні справи, касаційне оскарження, процесуальні фільтри, право на справедливий суд, значний суспільний інтерес, правове питання фундаментального значення, виняткове значення справи.

Постановка проблеми. Забезпечення права касаційного оскарження судових рішень належить до числа основоположних конституційних засад судочинства. При цьому п. 8 ч. 1 ст. 129 Конституції України передбачено можливість встановлення процесуальних фільтрів допуску окремих категорій цивільних справ до перегляду в суді касаційної інстанції, що загалом відповідає європейським стандартам доступності правосуддя та істотно не впливає на ефективність функціонування правового механізму забезпечення реалізації системи гарантій права на справедливий суд, передбачених абз. 1 ст. 6 Конвенції про захист прав людини і основоположних свобод (далі за текстом ЄКПЛ). 3-поміж широкого конгломерату різнорідних цивільних справ, чинним Цивільним процесуальним кодексом України (далі за текстом - ЦПК України) виділяється окрема, досить специфічна за своїм змістом та процесуальною формою розгляду, категорія останніх. Йдеться про справи, у яких ціна позову не перевищує ста розмірів прожиткового мінімуму для працездатних осіб, або так звані малозначні справи. Разом із тим не втрачає своєї актуальності проблема надмірного перевантаження національної судової системи та зумовленого цим перманентного пошуку можливих шляхів оптимізації процесуальних механізмів оскарження судових рішень. Саме з метою вирішення зазначеної вище проблеми було запроваджено процесуальний фільтр допуску малозначних справ до перегляду в суді касаційної інстанції. Зокрема, п. 2 ч. 3 ст. 389 чинного ЦПК України визначено, що не підлягають касаційному оскарженню судові рішення 
у малозначних справах та у справах з ціною позову, що не перевищує двохсот п'ятдесяти розмірів прожиткового мінімуму для працездатних осіб, крім випадків, установлених законом. У зв'язку з цим законодавцем було сформульовано дві групи підстав, за наявності яких малозначна справа може бути переглянута судом касаційної інстанції. Перша має універсальний, всезагальний характер і застосовується до всіх цивільних справ, незалежно від їх категорії, тоді як друга є спеціальною групою підстав, існування однієї з яких є обов'язковою умовою допуску малозначної справи до касаційного перегляду. Однак, закріпивши у п. 2 ч. 3 ст. 389 ЦПК України вичерпний перелік останніх, законодавець відобразив їх у формі абстрактно сформульованих оціночних категорій, не надавши будь-яких дефініцій, системи критеріїв чи факторів, які варто було б враховувати під час здійснення правозастосовної діяльності. Таким чином, виникла нагальна потреба доктринального тлумачення спеціальних підстав касаційного оскарження судових рішень у малозначних справах з метою забезпечення належного рівня ефективності правового регулювання, його цілеспрямованості та результативності. Відсутність єдиних підходів до інтерпретації законодавчо закріплених категорій, що мають відверто оціночний характер, i, як наслідок, глибока та істотна диверсифікація правозастосовної практики деструктивно впливають на співвідношення між очікуваним результатом та фактичними наслідками впливу права на суспільні відносини, тим самим нівелюючи соціальний ефект правового регулювання.

Аналіз останніх досліджень і публікацій. Питанням зловживання системою оскарження, встановлення і подолання процесуальних фільтрів допуску окремих категорій цивільних справ, у тому числі й малозначних, до перегляду в суді касаційної інстанції, а також процесуальних особливостей касаційного оскарження судових рішень у малозначних справах були присвячені праці вітчизняних вчених-процесуалістів: В. В. Комарова, Г. М. Ахмач, І. О. Ізарової, Д. Д. Луспеника, О. І. Попова, Н. Ю. Сакари, А. О. Селіванова, О. С. Ткачука та інших. Разом із тим, 3 огляду на перманентний характер новелізації цивільного процесуального законодавства, відносну абстрактність нормативно закріплених понять і категорій, а також в умовах обмеженого обсягу належної судової практики, відсутності прецедентів, роз'яснень і правових позицій вищих судових інстанцій не втрачає своєї актуальності проблема здійснення доктринального тлумачення законодавчих матерій, які мають оціночний характер, 3 метою уникнення стану правової невизначеності та подальшої диверсифікації правозастосовної практики.

Метою статті $є$ дослідження спеціальних підстав допуску малозначних справ до перегляду в суді касаційної інстанції, а саме: 1) з'ясування ступеня відповідності законодавчо встановлених обмежень стандартам Комітету Міністрів Ради Свропи та практиці Європейського суду з прав людини; 2) аналіз системи підстав касаційного оскарження судових рішень за чинним процесуальним законодавством; 3) визначення характеру співвідношення між універсальною та спеціальною групами підстав допуску малозначних справ до перегляду в суді касаційної інстанції; 4) тлумачення змісту спеціальних підстав касаційного оскарження судових рішень „ у малозначних справах.

Виклад основного матеріалу. Одним із найбільш складних та неоднозначних щодо можливих шляхів вирішення залишається питання процесуальних фільтрів перегляду справ із незначним розміром позовних вимог у суді касаційної інстанції. Проблема зловживання системою оскарження була і залишається предметом особливої уваги Комітету Міністрів Ради Європи, який у своїй Рекомендації щодо введення в дію та поліпшення функціонування систем і процедур оскарження в цивільних і торгових справах № $\mathrm{R}$ (95) 5 від 07.02.1995 р. рекомендував державам-членам виключити право апеляційного і касаційного оскарження за певними категоріями справ [1]. Наведене вище положення цілком узгоджується 3 правовими позиціями, сформованими Європейським судом 3 прав людини (далі за текстом - ССПЛ) у справах Levages Prestations Services v. France від 23 жовтня 1996 року та Brualla Gomez de la Torre v. Spain від 19 грудня 1997 року, де наголошується, що умови прийнятності касаційної скарги, відповідно до норм законодавства, можуть бути суворішими, ніж для звичайної заяви. Держава правомочна на власний розсуд встановлювати процесуальні фільтри допуску справи до касаційного перегляду, оскільки право касаційного оскарження за своєю природою є таким, що підлягає публічно-правовому регулюванню. Зважаючи на особливий статус суду касаційної інстанції, процедури касаційного перегляду можуть бути більш формальними, особливо якщо провадження у справі здійснюється після іï розгляду судами першої та апеляційної інстанцій [2].

Відсутність процесуальних фільтрів касаційного оскарження протягом досить 
тривалого часу залишалася основним фактором перевантаження суддів касаційної інстанції, що безпосередньо впливало на рівень ефективності відправлення правосуддя і виконання функцій вищих судових органів у системі судів загальної юрисдикції України, зокрема, в питаннях забезпечення сталості та єдності судової практики, а також однакового застосування норм матеріального і процесуального права судами нижчих інстанцій та відповідних спеціалізацій.

У чинному ЦПК України вирішено питання процесуальних фільтрів допуску окремих категорій справ, у тому числі малозначних, до перегляду в суді касаційної інстанції. Сучасна система касаційного оскарження малозначних справ охоплюе «універсальну» і «спеціальну» групи підстав, які $є$ взаємопов'язаними та мають застосовуватися одночасно. Як універсальні підстави для касаційного перегляду судових рішень ч. 2 ст. 389 ЦПК України передбачає неправильне застосування судом норм матеріального права чи порушення норм процесуального права у випадках: 1) якщо суд апеляційної інстанції в оскаржуваному судовому рішенні застосував норму права без урахування висновку щодо застосування норми права у подібних правовідносинах, викладеного у постанові Верховного Суду, крім випадку наявності постанови Верховного Суду про відступлення від такого висновку; 2) якщо скаржник вмотивовано обгрунтував необхідність відступлення від висновку щодо застосування норми права у подібних правовідносинах, викладеного у постанові Верховного Суду та застосованого судом апеляційної інстанції в оскаржуваному судовому рішенні; 3) якщо відсутній висновок Верховного Суду щодо питання застосування норми права у подібних правовідносинах; 4) якщо судове рішення оскаржується 3 підстав, передбачених ч. 1, 3 ст. 411 ЦПК України.

Група спеціальних підстав касаційного перегляду малозначних справ визначена у п. 2 ч. 3 ст. 389 ЦПК України, за яким не підлягають касаційному оскарженню судові рішення у малозначних справах та у справах із ціною позову, що не перевищує двохсот п'ятдесяти розмірів прожиткового мінімуму для працездатних осіб, крім випадків, якщо: 1) касаційна скарга стосується питання права, яке має фундаментальне значення для формування єдиної правозастосовчої практики; 2) особа, яка подає касаційну скаргу, позбавлена можливості спростувати обставини, встановлені оскарженим судовим рішенням, під час розгляду іншої справи; 3) справа становить значний суспільний інтерес або має виняткове значення для учас- ника справи, який подає касаційну скаргу; 4) суд першої інстанції відніс справу до категорії малозначних помилково. У всіх інших випадках суд відмовляє у відкритті касаційного провадження.

Універсальні та спеціальні підстави касаційного оскарження можна співвіднести крізь призму таких діалектичних категорій, як загальне й одиничне. Тому для відкриття касаційного провадження у малозначній справі не досить наявності підстав, визначених п. 2 ч. 3 ст. 389 ЦПК України, оскільки одиничне не може існувати окремо від загального, яке завжди втілюється в одиничному і реалізується через нього. Вони мають застосовуватися у сукупності, а їх зв'язок $є$ всеохоплюючим. Малозначну справу може бути допущено до касаційного перегляду лише за умови комплексності, тобто побіжної наявності однієї з універсальних та спеціальної підстав касаційного оскарження судових рішень у малозначних справах.

За таких обставин виникла ситуація невизначеності у розумінні та інтерпретації передбачених п. 2 ч. 3 ст. 389 ЦПК України підстав, за умови наявності яких цивільний процесуальний закон передбачає можливість подолання процесуального фільтру для перегляду малозначних справ у суді касаційної інстанції. При цьому поняття «значний суспільний інтерес», «виняткове значення справи», а тим більше «правове питання фундаментального значення» за своїм характером є оціночними, абсолютно абстрактними категоріями, тому в подоланні цієї невизначеності основоположна роль відводиться суддям різних інстанцій, які в процесі відправлення правосуддя у цивільних справах поступово напрацьовують відповідні матеріали судової практики, які наповнюють конкретним змістом законодавчі матерії. Мінімізація ризиків, пов'язаних із відсутністю нормативно визначених дефініцій, а відповідно, й превалюванням неоднозначності у розумінні змісту зазначених вище категорій, належить до дискреційних повноважень Верховного Суду. Така практика є загальновизнаною, прийнятою, узгодженою із міжнародними стандартами забезпечення доступу до правосуддя і безпосередньо сприяє досягненню сталості та єдності судової практики. Разом із тим не втрачає своєї актуальності питання доктринального тлумачення законодавчих матерій, яке, безумовно, має враховувати й органічно поєднувати в собі правові позиції та матеріали судової практики Верховного Суду.

За обсягом змісту категорію «питання права, яке має фундаментальне значення для формування єдиної правозастосовчої 
практики» можна розширено інтерпретувати, оскільки її законодавчо закріплене формулювання органічно орієнтоване на охоплення досить широкого кола правових явищ, які в системі процесуальних координат касаційного перегляду малозначних справ є найбільш істотними, проблемними та систематичними 3 точки зору правозастосування і забезпечення його одноманітності у подібних правовідносинах. Результати аналізу та узагальнення практики Верховного Суду дають можливість позначити декілька основних груп правових явищ, що $є$ факторами концептуалізації питань права, які мають фундаментальне значення для формування єдиної правозастосовчої практики, зокрема: 1) систематичне порушення права на справедливий судовий розгляд і обмеження системи гарантій, передбачених абз. 1 ст. 6 ЄКПЛ, внаслідок істотного та неодноразового порушення судами нижчих інстанцій норм процесуального права; 2) помилкове тлумачення i застосування судами нижчих інстанцій норм матеріального та/або процесуального права, що має системний і перманентний характер та $є$ детермінантами ухвалення незаконних і необгрунтованих рішень; 3) необхідності подолання в нормах процесуального та/або матеріального права прогалин і колізій засобами аналогії закону, аналогії права, а в особливих випадках - міжгалузевої аналогії 4) неодноразове порушення судами нижчих інстанцій вимог принципу пропорційності, коли провадження у малозначних справах здійснювалося без урахування завдань цивільного судочинства, особливостей предмета спору, ціни позову, складності справи, значення розгляду справи для сторін, часу, необхідного для вчинення тих чи інших дій, розміру судових витрат, пов'язаних із відповідними процесуальними діями, результатом чого стало порушення балансу між публічними і приватними інтересами; 5) систематичне ухвалення неправосудних рішень внаслідок перевищення повноважень судами нижчих інстанцій.

«Неможливість особою, яка подала касаиійну скаргу, спростувати обставини, встановлені оскарженим судовим рішенням, під час розгляду іншої справи» було вибрано як підставу подолання процесуального фільтру для перегляду малозначних справ у суді касаційної інстанції з огляду на трансцендентний характер преюдиціального зв'язку між окремими рішеннями суду, оскільки ті самі юридичні факти можуть мати різні правові наслідки за схожих життєвих обставин. Зазначена підстава охоплює досить широке коло суспільних відносин та індивідуальних життевих ситуацій, які важко теоретично спрогнозувати, а тим більше передбачити. Тому суд повинен у кожному конкретному випадку застосовувати індивідуальний підхід та ретельно аналізувати фактичні обставини справи, при цьому враховуючи, що обставини і факти, встановлені під час розгляду малозначної справи, набувають преюдиціального значення, а отже, не підлягають доказуванню під час розгляду іншої справи за правилами цивільного, господарського, адміністративного чи кримінального судочинства.

Малозначна справа, що розглядається в суді касаційної інстанції, може становити «значний суспільний інтерес» тільки в тому разі, якщо результати іï̈ перегляду прямо або опосередковано матимуть вплив на забезпечення реалізації системи гарантій права на справедливий суд, передбачених абз. 1 ст. 6 ЄКПЛ, та, як наслідок, визначення змісту та обсягу прав, свобод чи законних інтересів невизначеного кола осіб. Від рівня гарантованості суспільного інтересу залежить ступінь дотримання прав, свобод і законних інтересів окремих громадян. Таким чином, перегляд малозначної справи судом касаційної інстанції матиме значний суспільний інтерес у разі, якщо буде вирішуватися питання стосовно: 1) забезпечення однакового застосування норм матеріального і процесуального права судами нижчих інстанцій під час розгляду окремих категорій малозначних справ; 2) формулювання правового висновку (позиції) щодо застосування норми права у подібних правовідносинах; 3) досягнення і збереження сталості та єдності судової практики з розгляду деяких категорій малозначних справ; 4) судового тлумачення та подолання системних колізій і прогалин у нормах матеріального права.

Питання «винятковості значення» малозначної справи знаходиться в системі координат суддівської дискреції та, безумовно, має вирішуватися в контексті забезпечення реалізації та дотримання системи гарантій права на справедливий суд, прийняття законних і обгрунтованих рішень. 3 огляду на специфіку природи малозначних справ, суд касаційної інстанції, вирішуючи питання винятковості значення справи для ії учасників, має враховувати: а) ціну позову; б) характер спірних правовідносин; в) особливості предмета спору; г) складність справи; г) значення розгляду справи для сторін; д) час, необхідний для вчинення тих чи інших процесуальних дій; е) розмір судових витрат. Категорія «винятковість 
значення справи» є оціночною і підлягає поширювальному суддівському тлумаченню, тому охоплює собою досить широке коло індивідуальних життєвих ситуацій та конкретних фактичних обставин, які об'єктивно важко змоделювати і передбачити завчасно. Практика Верховного Суду дозволяє відійти від загальних і абстрактних критеріїв визначення ступеня винятковості справи та позначити конкретні обставини, що розглядаються судом касаційної інстанції як підстави для надання малозначній справі виняткового значення, зокрема: 1) порушення судами нижчих інстанцій вимог принципу пропорційності під час розгляду конкретної малозначної справи; 2) ухвалення судом першої інстанції незаконного та/або необгрунтованого судового рішення внаслідок помилки, яка була одночасно допущена або не виправлена судом апеляційної інстанції; 3) постановлення судами нижчих інстанцій відверто неправосудних рішень внаслідок перевищення повноважень та/або порушення закону.

Суд першої інстанції може «помилково віднести справу до категорії малозначних» лише у трьох випадках: 1) неправильно визначивши ціну позову; 2) застосувавши систему критеріїв, передбачених ч. 3 ст. 274 ЦПК України, до справи, яка повинна розглядатися за правилами загального позовного провадження, а не у спрощеному порядку; 3) у спорах немайнового характеру, де неможливо точно і однозначно визначити ціну позову, а оцінка ступеня відповідності справи системі критеріїв, передбачених ч. 3 ст. 274 ЦПК України, належить до дискреційних повноважень суду та здійснюється суддею на власний розсуд виходячи із суб’єктивних міркувань. Найбільш проблемною є остання ситуація, бо якщо у перших двох випадках наявність судової помилки $€$ очевидною, то у спорах немайнового характеру складно виявити малозначність, а тим більше на етапі відкриття касаційного провадження.

\section{Висновки}

Комплікативний характер системи підстав подолання процесуального фільтру зумовлений прагненням законодавця забезпечити більш високий стандарт касаційного оскарження малозначних справ. Наведене вище дає можливість стверджувати, що подібного роду практика жодним чином, безпосередньо чи опосередковано, не суперечить вимогам абз. 1 ст. 6 ЄКПЛ та відповідає конституційним засадам судочинства, зокрема п. 8 ч. 1 ст. 129 Конституції України, який гарантує право касаційного оскарження судового рішення, але у визначених законом випадках. При цьому слушною видається думка Д. Д. Луспеника, який вважає, що існування «процесуальних фільтрів» та процедури допуску ніяким чином не перешкоджає реалізації права на суд, оскільки останнє реалізується у разі звернення до суду першої та апеляційної інстанцій. Крім того, існування такого правового механізму є гарантією своєчасності усунення судових помилок та запорукою дотримання справедливого балансу між приватними і публічними інтересами [3, с. 40].

Разом із тим відсутність нормативно регламентованих критеріїв застосування підстав допуску малозначних справ до перегляду в суді касаційної інстанції утворює прогалину в законодавчому регулюванні, що безпосередньо впливає на якість процесуального закону та ефективність функціонування правового механізму забезпечення реалізації системи гарантій права на справедливий суд. Запровадження процесуального фільтру касаційного оскарження малозначних справ без вичерпної нормативної регламентації змісту підстав для його подолання та процесуальних критеріїв реалізації останніх породжує стан правової невизначеності, а відповідно, і непередбачуваності правових наслідків застосування законодавчо встановлених обмежень, що в контексті практики ЄСПЛ розглядається як порушення права на доступ до суду.

3 огляду на зазначене вище, особливого значення набуває практика Верховного Суду, за результатами аналізу якої можна синтезувати відносно абстрактні критерії, котрі комплексно дають можливість позначити вектори і межі суддівської дискреції. Більшість спеціальних підстав допуску малозначних справ до перегляду в суді касаційної інстанції є максимально абстрактними й оціночними категоріями, універсальну формулу застосування яких на рівні строкатого суддівського тлумачення сформулювати надзвичайно складно. У зв'язку з цим актуальним є питання внесення доповнень до ч. 3 ст. 389 ЦПК України 3 метою уточнення змісту і регламентації процесуального порядку та критеріїв застосування підстав касаційного оскарження малозначних справ. При цьому як проміжний етап, а також задля забезпечення однакового застосування положень п. 2 ч. 3 ст. 389 ЦПК України доречно на рівні Пленуму Верховного Суду здійснити узагальнення судової практики та сформулювати правові позиції Верховного Суду щодо критеріїв застосування підстав касаційного перегляду судових рішень у малозначних справах. 


\section{Список використаних джерел:}

1. Рекомендація № R (95) 5 Комітету Міністрів Ради Європи державам-членам щодо введення в дію та поліпшення функціонування систем та процедур оскарження у цивільних і торгівельних справах від 07 лютого 1995 року. URL: https:// zakon.rada.gov.ua/laws/show/994 153 (дата звернення: 10.05.2020).
2. Ухвала Верховного Суду від 26 березня 2018 р., судова справа № 183/1066/16. URL: http://reyestr.court.gov.ua/Review/72970244 (дата звернення: 11.05.2020)

3. Луспеник Д. Д. Ідеальний Процесуальний кодекс: яким він має бути? Украӥна на шляху до Свропи: реформа иивільного прочесуального законодавства : матеріали Міжнародної науково-практичної конференції (Київ, 7 лип. 2017 р.). Київ, 2017. С. 36-47.

Kostiantyn Bilous. Special grounds for cassation appeal of court decisions in minor cases

The article is devoted to the study of the content of special grounds for admission of insignificant cases for review in the court of cassation. The author found that the introduction of procedural filters for cassation appeals of certain categories of civil cases, including minor ones, does not contradict the standards set out in the Recommendations of the Committee of Ministers of the Council of Europe and does not significantly affect the level of efficiency of the legal mechanism to ensure the implementation of the system of guarantees of the right to a fair trial which is reflected in the case law of the European Court of Human Rights. According to the results of the analysis of the current procedural legislation, in particular the rules determining the procedural features of the cassation appeal of court decisions in minor cases, a "universal" and a "special" group of grounds for admitting minor cases for review by a court of cassation were distinguished which are correlated by the author through the prism of such dialectical categories as general and singular.

The author established that the existence of cassation proceedings in a minor case is not enough to have only special grounds since the singular cannot exist separately from the general which is always embodied in the singular and realized through it. A minor case may be admitted to the cassation review only if it is comprehensive that is, the fleeting existence of one of the universal and special grounds for cassation appeal of court decisions in minor cases. They must be applied together, and their connection is all-encompassing. The article provides the author's interpretation of the content of special grounds for admission of minor cases to review by the court of cassation, in particular: 1) the issue of law, which is fundamental for the formation of a unified law enforcement practice; 2) the inability of the person who filed the cassation appeal to refute the circumstances established by the appealed court decision when considering another case; 3) significant public interest of the case; 4) the exceptional significance of the case for its participant; 5) erroneous assignment of the case to the category of insignificant by the court of first instance.

Key words: minor cases, cassation appeal, procedural filters, right to a fair trial, significant public interest, legal issue of fundamental importance, exceptional significance of the case. 